\title{
Perspective for Part III
}

\author{
Toshio Nakanishi
}

The ductus arteriosus (DA) is open before birth and normally closes after birth. The unique anatomy and normal and abnormal behavior of the DA are discussed by Gittenberger, Shelton, and Sterren in this chapter.

The DA sometimes closes before birth or does not close after birth; both situations cause problems. Normally only $10-20 \%$ of right ventricular output goes to the lung and the rest goes to the aorta though DA during fetal life. If the DA closes before birth, right ventricular afterload increases because the right ventricle has to eject blood to the lung, which has high pulmonary arterial resistance. Early closure of the DA may result in right ventricular hypertrophy and somehow left ventricular dilatation [1].

If the DA does not close after birth, left (aorta) to right (pulmonary artery) shunt occurs, resulting in patent DA. In congenital heart diseases with severe outflow stenosis or atresia to the pulmonary artery, pulmonary circulation is dependent on the DA from the aorta. In hypoplastic left heart syndrome, systemic circulation is dependent on the DA from the pulmonary artery. Thus, the DA is clinically an important bridge over troubled vessels.

The precise mechanisms for the DA closure after birth remain unclear. The trigger for the DA closure is most likely $\mathrm{O}_{2}$, but how $\mathrm{O}_{2}$ causes DA closure has not been clarified. We [2] reported that ATP-sensitive $\mathrm{K}$ channel (KATP) might be an $\mathrm{O}_{2}$ sensor, which causes DA closure based on in vitro experiments. Momma et al. also report in this symposium that inhibition of KATP results in closure of DA in in vivo experiments. The group of Archer, however, reported that voltage-dependent $\mathrm{K}$ channels (Kv) might be an $\mathrm{O}_{2}$ sensor [3, 4]. They suggest that $\mathrm{Kv}$ channels close in the DA, resulting in DA closure, and open in the pulmonary artery, resulting in pulmonary artery dilation, in response to $\mathrm{O}_{2}$ and reactive oxygen species produced in mitochondria.

\footnotetext{
T. Nakanishi $(\bowtie)$

Department of Pediatric Cardiology, Tokyo Women's Medical University, Tokyo, Japan

e-mail: nakanishi.toshio@twmu.ac.jp
} 
In addition to $\mathrm{O}_{2}$, prostaglandin $\mathrm{E}$ plays an important role in opening DA before birth and closure of DA after birth. Prostaglandin E concentration in the neonatal blood decreases after birth, facilitating DA closure. Furthermore, Yokoyama et al. $[5,6]$ have shown that prostaglandin E and its receptor EP4 promote neointimal formation during fetal life and inhibit elastic fiber formation, preparing DA closure after birth.

The DA is such an important and interesting vessel. Further investigation of the $\mathrm{O}_{2}$ sensor in the DA is necessary because the $\mathrm{O}_{2}$ sensor is biologically important not only in the DA but also in other vessels such as the pulmonary artery. Basic research regarding arterial elastogenesis could be expanded to the aorta in which the elastic fiber is disrupted in some patients with tetralogy of Fallot [7].

\section{References}

1. Momma K, Takao A. Right ventricular concentric hypertrophy and left ventricular dilatation by ductal constriction in fetal rats. Circ Res. 1989;64:1137-46.

2. Nakanishi T, Gu H, Hagiwara N, Momma K. Mechanisms of oxygen-induced contraction of ductus arteriosus isolated from the fetal rabbit. Circ Res 1993;72(6):1218-1228.

3. Tristani-Firouzi M, Reeve HL, Tolarova S, Weir EK, Archer SL. Oxygen-induced constriction of rabbit ductus arteriosus occurs via inhibition of a 4-aminopyridine-, voltage-sensitive potassium channel. J Clin Invest. 1996;98:1959-65.

4. Kajimoto H, Hashimoto K, Bonnet SN, Haromy A, Harry G, Moudgil R, Nakanishi T, Rebeyka I, Thébaud B, Michelakis ED, Archer SL. Oxygen activates the Rho/Rho-kinase pathway and induces RhoB and ROCK-1 expression in human and rabbit ductus arteriosus by increasing mitochondria-derived reactive oxygen species: a newly recognized mechanism for sustaining ductal constriction. Circulation 2007;115(13):1777-1788.

5. Yokoyama U, Minamisawa S, Quan H, Ghatak S, Akaike T, Segi-Nishida E, Iwasaki S, Iwamoto M, Misra S, Tamura K, Hori H, Yokota S, Toole BP, Sugimoto Y, Ishikawa Y. Chronic activation of the prostaglandin receptor EP4 promotes hyaluronan-mediated neointimal formation in the ductus arteriosus. J Clin Invest 2006;116(11):3026-3034.

6. Yokoyama U, Minamisawa S, Shioda A, Ishiwata R, Jin MH, Masuda M, Asou T, Sugimoto Y, Aoki H, Nakamura T, Ishikawa Y. Prostaglandin E2 inhibits elastogenesis in the ductus arteriosus via EP4 signaling. Circulation 2014;129(4):487-496.

7. Niwa K, Perloff JK, Bhuta SM, Laks H, Drinkwater DC, Child JS, Miner PD. Structural abnormalities of great arterial walls in congenital heart disease: light and electron microscopic analyses. Circulation 2001;103(3):393-400. 
Open Access This chapter is licensed under the terms of the Creative Commons Attribution 4.0 International License (http://creativecommons.org/licenses/by/4.0/), which permits use, sharing, adaptation, distribution and reproduction in any medium or format, as long as you give appropriate credit to the original author(s) and the source, provide a link to the Creative Commons license and indicate if changes were made.

The images or other third party material in this chapter are included in the chapter's Creative Commons license, unless indicated otherwise in a credit line to the material. If material is not included in the chapter's Creative Commons license and your intended use is not permitted by statutory regulation or exceeds the permitted use, you will need to obtain permission directly from the copyright holder. 